6-3-2016

\title{
Film Reviews: Franco's Forgotten Children and Give Me Back My Child!
}

Ruth Amir

Yezreel Valley College

Follow this and additional works at: https://digitalcommons.usf.edu/gsp

\section{Recommended Citation}

Amir, Ruth (2016) "Film Reviews: Franco's Forgotten Children and Give Me Back My Child!," Genocide Studies and Prevention: An International Journal: Vol. 10: Iss. 1: 124-128.

DOI:

http://dx.doi.org/10.5038/1911-9933.10.1.1421

Available at: https://digitalcommons.usf.edu/gsp/vol10/iss1/14

This Film Review is brought to you for free and open access by the Open Access Journals at Digital Commons @ University of South Florida. It has been accepted for inclusion in Genocide Studies and Prevention: An International Journal by an authorized editor of Digital Commons @ University of South Florida. For more information, please contact digitalcommons@usf.edu. 


\author{
Ruth Amir \\ Yezreel Valley College \\ Emek Yezreel, Israel
}

Franco's Forgotten Children

Directors: Montse Armengou, Ricard Belis

Spain, 2002.

Give Me Back My Child!

Directors: Montse Armengou, Ricard Belis

Spain, 2011.

Reviewed by Ruth Amir

Yezreel Valley College

Emek Yezreel, Israel

The two documentary films, Franco's Forgotten Children, and Give Me Back My Child!, both by Montse Armengou and Ricard Belis, single out the particular evils perpetrated on women and children during the Spanish civil war and Franco's dictatorship. ${ }^{1}$ A 2003 volume entitled Los Niños Perdidos del Franquismo is the result of collaboration between the filmmakers and Ricard Vinyes, Professor of History at the University of Barcelona. ${ }^{2}$

Franco's Forgotten Children tells the suppressed story of Franco's attempt to wipe out from Spain the supporters of the Second Republic. Army Commander and Psychiatrist Antonio Vallejo Nágera was Franco's pseudo-scientific ideologue. He developed a eugenic theory based on German doctrines of racial hygiene and Catholic moral doctrine. On 23 August 1938, Franco authorized Vallejo Nágera to study the biopsychic roots of Marxism in search of the red gene, allegedly carried by the Republicans, and to cleanse Spain of the so called degenerative elements. ${ }^{3}$ Vallejo Nágera conducted psychiatric experiments on women, Republicans, International Brigades prisoners. He concluded that Marxism goes together with social immorality, and Marxist are "social imbeciles." 4

The filmmakers compare Franco's use of a [pseudo] scientific theory - the underlying ideology used by the regime for the legitimation of the outrageous treatment of Republicans - with that of Nazi Germany. Indeed, Vallejo Nágera served in the military department of the Spanish Embassy in Berlin where he became acquainted with German psychiatrists and their work. However, this similarity was not limited to the realm of theory. Franco's Falanges ruthlessly persecuted the vanquished Republicans and their families through executions and imprisonment, in a manner similar to the Nazi persecution of the Jews and other minorities.

The viewers are presented with several profiles of survivors of Franco's concentration camps and prisons. These are women who attempted to flee Spain by sea from Alicante and Valencia and were forcibly disembarked; women who were guilty by association as spouses, mothers or sisters, and children of Republican parents or people targeted by the Francoists. The survivors describe the inhumane conditions, the torture, violence, disease, and hunger. Many children were taken into the camps along with their mothers, or were born in captivity sometimes as the result of rape. Special prisons were designed for lactating mothers. The conditions at these camps and prisons were appalling. Children who did not perish from hunger or disease were often kept in the camps and prisons until their mothers were released, or until they reached the age of three years. Although, sometimes the children were shot by firing squads sometime after their mothers gave birth.

\footnotetext{
${ }^{1}$ Montse Armengou and Ricard Belis, Franco's Forgotten Children, (Catalunya TV3, 2002); Montse Armengou and Ricard Belis, Give Me Back My Child!, (Catalunya TV3, 2011).

${ }^{2}$ Ricard Vinyes, et al., Los niños perdidos del Franquismo (Barcelona: Debolsillo, 2003), 314.

${ }^{3}$ Paul Preston. The Spanish Civil War: Reaction, Revolution and Revenge (New York: W.W. Norton \& Co., 2007), 310. Giles Tremlett. Ghosts of Spain: Travels through a Country's Hidden Past (London: Faber and Faber, 2006), 63.

${ }^{4}$ Antonio Vallejo Nágera, "Psiquismo del Fanatismo Marxista," Semana Médica Española 6 no. 1 (1938): 172-180.
} 
The separation of children from their parents was authorized by law. The Spanish Law on the Protection of Orphans 1940 gave the government custody over children whose moral education was allegedly at risk. The law stipulated that the children were to remain with their incarcerated mothers until the age of three. However, by the end of 1940 only parents with flawless religious, national and moral credentials could continue raising their children. ${ }^{5}$ The children were placed in orphanages and religious institutions where they were systematically brainwashed to despise their parents' ideals and serve Franco's regime. Many of these children were given up for adoption to Franco's supporters and were never reunited with their families.

The testimonies are devastating and empowering at the same time. They tell the horrors of the perpetrators' unspeakable crimes, but also attest to the survivors' stamina and fortitude. Survivors are often glorified for their resilience, mainly for adapting well in the face of a catastrophe or trauma. Yet the reference to the survivors' resilience could be a projection or a collective wishful thinking operating through society's mechanisms of autopoiesis and its drive towards resuming social order. At the same time, the attribution of resilience is at the same time deceiving for it often downplays the long-term consequences of the atrocities. Hence, while survivors can never really overcome the losses and the absence of loved ones, they are expected to submit to the supposed healing function of the passage of time, or the termination of the oppressive regime.

This ambivalence is clearly evident in the testimonies. For example, Carme Riera was three month pregnant and got married the night before her husband faced the firing squad. She was imprisoned for being the wife of a trade unionist and her daughter was born in prison in Saturraran in the Basque country. Upon her return to Saturraran beach, Riera says: "I am here today, I wear a smile on my face, but I am not smiling inside ... because I remember everything that went on there." 6 This is also evident in the stories of the other women who faced tough choices. After describing the painful death of her infant, Julia Manzanal concludes: "Her fate was sealed at her mother's womb. I was fighting for a cause but she was the one to be sentenced."

Give Me Back My Child! is in a sense an upshot of Franco's Forgotten Children. The film begins with 3D ultrasound image of a fetus in utero and a woman in labor. A voiceover reminds the viewers of the shockwaves Armengou and Belis' film Franco's Forgotten Children sent throughout Spain. It is then followed by a trailer from Franco's Forgotten Children.

Give Me Back My Child! focuses on the oppressive mechanisms of child appropriation that were part of routine life during Franco's dictatorship. It unfolds the coercion, illegal adoptions, the changing of names and identities, and trafficking of children. These were aided by the Parto Anónimo (anonymous birth) law that allowed for concealing the mother's identity after birth, pursuant to an interpretation of the Civil Registration Act of 1957 and the Civil Registration Regulations of $1958 .{ }^{8}$ These enabled the adoptive mother, who was sometimes encouraged to fake a pregnancy, to register as the child's biological mother. For the biological mother, an anonymous birth meant a point of no return. She had lost all her maternal rights and was not granted the possibility to rethink her decision after several months. In 1999 the Spanish Supreme Court ruled that the Parto Anónimo was unconstitutional. ${ }^{9}$

Whereas the kidnapping and illegal adoptions of children under Franco's dictatorship did not target any group in particular and were allegedly individual-based crimes, they originated from the same ideological state apparatuses as Vallejo Nágera's eugenic aspirations and the Catholic Church's notions of morality. In contrast to the forcible separation of Republican children, however, the trafficking of children was also motivated by economic gains to those actively involved.

\footnotetext{
${ }^{5}$ Ricard Vinyes, "Las desapariciones infantiles durante el Franquismo y sus Consecuencias," International Journal of Iberian Studies 19 (2006): 60.

${ }^{6}$ Armengou and Belis, Franco's Forgotten Children, 027:00-027:17.

${ }^{7}$ Armengou and Belis, Franco's Forgotten Children, 023:53-023:57.

${ }^{8}$ See the Spanish Civil Registration act, Ley de 8 de junio de 1957, del Registro Civil, available at http://noticias.juridicas. com/base datos/Privado/Irc.t1.html, art. 47, accessed August 20, 2015; Civil Registration Regulations, Decreto de 14 de noviembre de 1958, por el que se aprueba el Reglamento para la aplicación de la Ley del Registro Civil. Available at http://noticias.juridicas.com/base datos/Privado/rrc.t5.html, art. 167, accessed August 20, 2015.

${ }^{9}$ See the ruling of the Spanish Supreme, Recurso de Casacion num. 2854/1994, Sentencia del TS, September 21, 1999.
} 
Armengou and Belis tell the story of the consequences of identity changes and the destruction of official birth documents, and their effect on both the then-children and mothers. They also investigate the networks and mechanisms of trafficking and key figures. One such network, Maria Madre, was established by Doña Mercedes Herrán de Gras. Maria Madre was a charitable fund that maintained apartments for pregnant women who allegedly conceived in sin and had to give their babies for adoption. Maria Madre and other organizations like Santa Isabel and Via Teresita were spread out across Spain, supplying newborns to adoptive parents. According to the filmmakers, there were hundreds of cases in which the parents were told that their baby had died at birth or shortly afterwards when it was actually put up for adoption.

Both documentaries resist Spain's Pacto del Olvido (the pact of forgetting), a tacit agreement to leave the past behind. Apparently, the agreement reached by the political leaders was to ease Spain's transition to democracy. ${ }^{10}$ The pact of forgetting was reinforced and enhanced by the Amnesty law of 1977 that afforded the release of all political prisoners and prevented the prosecution of Francoist perpetrators who committed politically-motivated crimes prior to the transition to democracy. ${ }^{11}$ As Paloma Aguilar suggests, "the two sides ended up reaching a kind of agreement regarding their mutual guilt." ${ }^{12}$ Nevertheless, this law was criticized by numerous international human rights bodies, such as the Human Rights Committee (HRC) and the Committee against Torture (CAT) ${ }^{13}$

Franco's Forgotten Children was aired in 2002, at a time when the organization for the recovery of historical memory (ARMH), a non-profit organization established by the United Left Party in 2000 , exhumed mass graves and attempted to identify the remains of the victims. ${ }^{14}$ Give Me Back My Child! was aired four years after the enactment of the Historical Memory Law in 2007. ${ }^{15}$ This Law has acknowledged the crimes and violations of Francoism and Judge Garzón's investigations and exhumations.

Both documentaries draw on original, in-depth research and field-work. They use witnesses and survivors' narratives to counter the denial of those involved in the trafficking of children, including nurses, mediators, and doctors, historic film reels of happy and well-groomed children, documents, propaganda, and the (pseudo) scientific basis of the ideology that legitimated these atrocities. The films provide a severe charge sheet against the Catholic Church and its outrageous direct involvement in the atrocities. ${ }^{16}$ Both films reveal, through the testimonies of women and then-children the extent and devastating consequences of the atrocities. Yet, the filmmakers succeed in not falling into a privatized sentimental narrative of the victims. The individual stories are carefully interwoven into the larger picture and the political, social, and economic context of the events. In this, both films feed the resurgence of interest and activism in Spain's repressive legacy and the array of official responses. ${ }^{17}$

\footnotetext{
${ }^{10}$ See Paul Preston's account of the Pacto del Olvido in Paul Preston, The Politics of Revenge: Fascism and the Military in Twentieth-Century Spain (London and New York: Routledge, 1995), 33-34. Madeleine Davis, "Is Spain Recovering its Memory? Breaking the Pacto Del Olvido." Human Rights Quarterly 27 no. 3 (2005): 858-880.

${ }^{11}$ See the Spanish Amnesty Law, Ley 46/1977 Amnistia, art. 2 (15 Oct. 1977) (Spain), available online at http://www.boe. es/boe/dias/1977/10/17/pdfs/A22765-22766.pdf accessed September 19, 2015. See Paloma Aguilar, "Justice, Politics and Memory in the Spanish Transition," in The Politics of Memory, ed. Alexandra Barahona De Brito et al. (London: Oxford University Press, 2001), 104.

${ }^{12}$ Paloma Aguilar, Memory and Amnesia: The Role of the Spanish Civil War in the Transition to Democracy (New York: Berghahn Books, 2002), 132.

${ }^{13}$ Fifth Periodic report of Spain, UN Doc. CCPR/ESP/CO/5, 27 October 2008, para. 9); AT/C/ESP/CO/5, 9 December 2009, see para. 21.

${ }^{14}$ On the jurisdictional obstacles to prosecution of Franco-Era perpetrators see Angela M. Guarino, "Chasing Ghosts: Pursuing Retroactive Justice for Franco-Era Crimes Against Humanity," Boston College International and Comparative Law Review Vol. 33, no. 1 (2010): 61-85.

${ }^{15}$ See the Spanish Historical Memory law, Ley de la Memoria Histórica (Ley 52/2007 26 December 1977) (Spain) available online at http://www.boe.es/boe/dias/2007/12/27/pdfs/A53410-53416.pdf (accessed September 19, 2015) See an English translation of the Law at http://www.derechos.org/nizkor/espana/doc/lmheng.html accessed August 1, 2015.

${ }^{16}$ See the 2002 award-winning The Magdalene Sisters by Peter Mulan on the Magdalene asylums for fallen women; Stephen Frears' Philomena (2013), and Jim Loach's Oranges and Sunshine (2012) about the British children forcible migration to Australia. All these films are based on books.

${ }^{17}$ See Aguilar, "Justice, Politics and Memory in the Spanish Transition" and Davis "Is Spain Recovering its Memory?," 862-863.
} 
Documentary films can be powerful sources of evidence, advocacy and recognition. Indeed, Franco's Forgotten Children and Give Me Back My Child!, provide a form of truth-telling that is much-needed in societies confronting and reconciling with dark pasts. Both films appeal to the viewers' moral conscience. They not only recreate the wrongfulness of the past through the documents and the historic visuals, but also show how such wrongdoings have shaped present lives. Moreover, they steer the viewers to reflect upon the intergenerational effects of both atrocities.

From the point of view of genocide research, the films pinpoint the two major shortcomings of the legal definition of genocide adopted by the United Nations Convention on the Prevention and Punishment of Genocide; namely denying the protection of political groups, and the proof of specific intent. Raphael Lemkin himself was ambivalent about granting protection to political groups, particularly in the context of civil wars or revolutions. He writes: "Should the state allow a revolutionary group to overthrow by violence its constitution, to burn its parliament, to destroy its courts, even for the sake of a higher and better form government? On the other hand, should we allow a government which fights a revolution to exterminate its political opponents?"18 Yet, Lemkin who had a soft spot for children was strongly opposed to forcible transfers of children. While the Spanish case is not considered genocide in the formal-legal sense, some argue that there are hermeneutical and comparative grounds for considering it as such. ${ }^{19}$

While atrocities perpetrated on women and children are considered particularly heinous, some acts seem to be open to interpretations and justifications that resist the application of existing legal instruments. Perpetrators often attempt the laundering of heinous atrocities towards children by alleging that they were enacted out of benevolent motives. A related argument made in reference to historical violations is that the norms and conduct that are now considered gross violations of human rights were part of a legitimate positivistic politico-ideological doctrine grounded in scientific knowledge. In other words, those seeking to suppress and obscure these atrocities consider them a temporal event and an isolated occurrence. Yet, the prevalence of similar cases across the world at approximately the same period warrants the attention of genocide scholars.

Title of the Film: Los niños perdidos del franquismo (Franco's Forgotten Children); Directors: Montse Armengou, Ricard Belis; Producer: Muntsa Tarrés; Screenplay: Montse Armengou, Ricard Belis; Cinematography: Walter Ojeda; Film Editor: Maria Josep Tubella; Country: Spain; Year of Release: 2002; Production Company: Televisió de Catalunya. Duration: 120 minutes.

Title of the Film: ¡Devolvedme a mi hijo! (Give Me Back my Child!); Directors: Montse Armengou, Ricard Belis; Producers: Tonà Julia, Jordi Campàs; Screenplay: Montse Armengou, Ricard Belis; Cinematography: Carles de la Encarnación; Film Editor: Maria Josep Tubella; Country: Catalunya, Spain; Year of Release: 2011; Production Company: Televisió de Catalunya. Duration: 78 minutes.

\section{Bibliography}

Aguilar, Paloma. "Justice, Politics and Memory in the Spanish Transition." In The Politics of Memory, edited by Alexandra Barahona DeBrito, Carmen Gonzalez Enriquez, and Paloma Aguilar, 92118. London: Oxford University Press, 2001. http://dx.doi.org/10.1093/0199240906.003.0004

Aguilar, Paloma. Memory and Amnesia: The Role of the Spanish Civil War in the Transition to Democracy. New York: Berghahn Books, 2002.

Davis, Madeleine. "Is Spain Recovering its Memory? Breaking the Pacto Del Olvido." Human Rights Quarterly 27, no. 3 (2005): 858-880. http://dx.doi.org/10.1353/hrq.2005.0034

Guarino, Angela M. "Chasing Ghosts: Pursuing Retroactive Justice for Franco-Era Crimes Against Humanity." Boston College International and Comparative Law Review Vol. 33 no. 1 (2010): 61-85.

\footnotetext{
${ }^{18}$ Raphael Lemkin. “The Nature of Genocide”. Unpublished Raphael Lemkin Collection, (Boston and New York: American Jewish Historical Society, Undated), Box 7, Folder 2.

${ }^{19}$ Antonio Miguez Macho, "A Genealogy of Genocide in Francoist Spain," Genocide Studies and Prevention: An International Journal Vol. 8 no. 1 (2013), 22. Paul Preston uses the term the Spanish Holocaust as a title for his book on the Civil War, see Paul Preston, The Spanish Holocaust: Inquisition and Extermination in Twentieth-Century Spain (London: Harper Press, 2012).
} 
Lemkin, Raphael. "The Nature of Genocide", in Unpublished Raphael Lemkin Collection, Boston and New York: American Jewish Historical Society, Undated.

Miguez Macho, Antonio. "A Genealogy of Genocide in Francoist Spain." Genocide Studies and Prevention: An International Journal Vol. 8 no. 1 (2013): 21-32. http://dx.doi.org/10.5038/19119933.8.1.4

Preston, Paul. The Politics of Revenge: Fascism and the Military in Twentieth-Century Spain. London and New York: Routledge, 1995.

Preston, Paul. The Spanish Civil War: Reaction, Revolution and Revenge. New York: W.W. Norton \& Co., 2007.

Preston, Paul. The Spanish Holocaust: Inquisition and Extermination in Twentieth-Century Spain. London: Harper Press, 2012.

Tremlett, Giles. Ghosts of Spain: Travels through a Country's Hidden Past. London: Faber and Faber, 2006.

Vallejo Nágera, Antonio. "Psiquismo del Fanatismo Marxista." Semana Médica Española 6 no. 1 (1938): 172-180.

Vinyes, Ricard, Montse Armengou, and Ricard Belis. Los niños perdidos del Franquismo. Barcelona: Debolsillo, 2003. 